\title{
Basidiomycetes at the timberline in Lapland 2. An annotated checklist of the polypores of northeastern Finland
}

\author{
PERTTI RENVALL, TARJA RENVALL and TUOMO NIEMELÄ
}

\begin{abstract}
RENVALL, P., RENVALL, T. \& NIEMELÄ, T. 1991: Basidiomycetes at the timberline in Lapland 2. An annotated checklist of the polypores of northeastern Finland. Karstenia 31:13-28.

Seventy-seven polypores are listed from virgin forests in northeastern Finland, ten of which are classified as threatened in Finland. The host range and abundance of each species are given. The occurrences of threatened and also some abundant species are treated with special reference to their distribution and habitat ecology. Fungal species compositions of spruce, pine and birch forests are compared: 33 species were recorded growing on Picea abies subsp. obovata, 31 species on Pinus sylvestris and 24 species on Betula pubescens. The economically most harmful pathogenic polypores found in the study area were Climacocystis borealis (Fr.) Kotl. \& Pouz., Fomes fomentarius (L.: Fr.) Fr., Fomitopsis pinicola (Sw.: Fr.) Karst., Inonotus obliquus (Pers.: Fr.) Pil., Onnia leporina (Fr.) Jahn, Piptoporus betulinus (Bull.: Fr.) Karst. and Porodaedalea chrysoloma (Fr.) Fiass. \& Niemelä. Problems in estimating abundances of wood-rotting fungi are discussed. The term boreo-continental is proposed to replace the misinterpreted concept 'taiga species' for a northeastern distributional pattern. The ecological role of wood-rotting fungi in a northern ecosystem, and yearly variation in fruit-body emergence are discussed. A new combination Skeletocutis lenis (Karst.) Niemelä is proposed and the background of the combination is briefly discussed.
\end{abstract}

Key words: Boreo-continental, Finland, Northern Boreal, polypores, primeval forest, Skeletocutis lenis, threatened fungi, timberline

Pertti Renvall, Tarja Renvall \& Tuomo Niemelä, Botanical Museum, University of Helsinki, Unioninkatu 44, SF-00170 Helsinki, Finland

\section{Introduction}

This is the second paper in a series devoted to the basidiomycetes at the timberline in Lapland, northern Finland. The background for the studies, previous mycological literature, general geography and vegetation of the research area were treated in detail in an introductory paper (Renvall et al. 1991). We here list the polypores of our study area in northeastern Finland, and outline the habitat ecology, occurrence, pathogenicity and distribution patterns of selected species. Special attention will be paid to threatened species.

\section{Material, methods and nomenclature}

The field work was done in 1987-1989 by P. Renvall and T. Renvall in the Värriö Strict Nature Reserve, the Urho Kekkonen National Park and the Tuntsa forest-fire area. Altogether 2600 records of polypores were made and 738 specimens were collected. For a closer description, see Renvall et al. (1991). Sight records were considered adequate for the species common in the study area and easily identifiable in the field such as:

Amylocystis lapponica (Rom.) Sing.

Amyloporia xantha (Fr.: Fr.) Bond. \& Sing. 
Cerrena unicolor (Bull.: Fr.) Murr.

Climacocystis borealis (Fr.) Kotl. \& Pouz.

Coltricia perennis (L.: Fr.) Murr.

Fomes fomentarius (L.: Fr.) Fr.

Fomitopsis pinicola (Sw.: Fr.) Karst.

F. rosea (Alb. \& Schw.: Fr.) Karst.

Fuscoporia viticola (Schw. ex Fr.) Donk

Inonotus obliquus (Pers.: Fr.) Pil.

Phellinus igniarius (L.: Fr.) Quél.

P. nigrolimitatus (Rom.) Bourd. \& Galz.

Piptoporus betulinus (Bull.: Fr.) Karst.

Porodaedalea chrysoloma (Fr.) Fiass. \& Niemelä

Trichaptum abietinum (Pers.: Fr.) Ryv.

The species in the Phellinus igniarius complex will be treated here collectively. An extensive study by Fischer (1987) on the subdivision of the group is not easily applied to our northern material, and we were forced to accept a broad, albeit conservative concept. So, for instance, the species $P$. nigricans (Fr.) Karst., $P$. cinereus (Niemelä) Fischer and $P$. alni (Bond.) Parm. are included in $P$. igniarius (L.: Fr.) Quél. The former Phellinus s. lat. is here divided into smaller units according to the proposal of Fiasson and Niemelä (1984). The new typification of the name Phellinus seems to bring about a wave of name changes. Fiasson and Niemelä (1984) understood Phellinus as typified by Polyporus rubriporus Quél. (P. torulosus (Pers.) Bourd. \& Galz.), which has been a generally accepted opinion for 30 years (cf. Donk 1960, 1974, Ryvarden 1976, 1978, Ryvarden \& Johansen 1980, Tellería 1980, Fiasson \& Niemelä 1984, Gilbertson \& Ryvarden 1987, Larsen \& CobbPoulle 1990). However, in the new Code of Botanical Nomenclature (Greuter et al. 1988) Phellinus is proposed to be conserved and typified according to $P$. igniarius, which would replace Ochroporus and necessitate selection of new generic name for $P$. torulosus and its allies. Here, the name Phellinus has been adopted for the $P$. igniarius complex after discussions with Prof. Erast Parmasto and Dr. Leif Ryvarden.

In connection with collecting and observing the fruit bodies of polypores, notes were made of the host tree, its degree of decay, other basidiomycetes growing on the same unit of wood and the forest vegetation of the habitat. At the end of each collecting day, the specimens were dried in a mushroom dryer in 35$40^{\circ} \mathrm{C}$.

We studied all specimens in the microscope. The chemical reagents that we used in the microscopical examination and their reactions are those listed by Niemelä $(1985 a, b)$. The material collected is mainly preserved in the Botanical Museum of the University of Helsinki (H) (see Renvall et al. 1991). In the text, initials and numbers, for instance PR 1913, stand for the collector and the collection number. The localities of the rarest species will be indicated according to the
National Uniform Grid System (see Heikinheimo \& Raatikainen 1971).

The polypore species growing on conifers and on the ground have been studied and discussed by $\mathrm{P}$. Renvall, while the species inhabiting broad-leaved trees have been studied also by T. Renvall. The introduction and the notes on abundance, distribution and other discussions have been written mostly by $\mathrm{P}$. Renvall. T. Niemelä assisted in writing the final version of the paper and the taxonomy of Skeletocutis lenis has been discussed by him. The photographs in this article were taken by P. Renvall, and the drawing of Skeletocutis lenis is by T. Niemelä.

\section{Abundance}

Several problems are found in estimating and describing the abundance of wood-inhabiting fungi. The truly correct way would be to study the proportions of mycelia of different species and fungal individuals within wood units. However, our opinion is that the comparison of fruit body frequencies gives a reliable general indication of the abundances of fungal species. We used a six-point scale for the purpose:

$\begin{array}{lc}\text { Class of abundance } & \text { Number of finds } \\ \text { very rare (vr) } & 1-2 \\ \text { rare }(\mathrm{r}) & 3-10 \\ \text { fairly rare (fr) } & 11-20 \\ \text { fairly common (fc) } & 21-30 \\ \text { common (c) } & 31-80 \\ \text { very common (vc) } & >80\end{array}$

The above rating was made for a material totalling 2600 observations (collections plus sight records). The distribution of the species among the different abundance classes is shown in Fig. 1; this should help to make strongly deviating numbers of observations comparable. Such a comparison can be desirable, for instance, when different forest areas are assessed with regard to their species spectra and their value for conservation.

A more exact census of fungal individuals within wood units would be possible, too. In certain primary wood-rotting fungi, single individuals are known to penetrate throughout their tree trunks or stumps (Rayner \& Boddy 1988): examples are Phaeolus schweinitzii (Fr.) Pat., Fomitopsis pinicola (Sw.: Fr.) Karst. and Piptoporus betulinus (Bull.: Fr.) Karst. On the other hand, host tree units inhabited by Trametes versicolor (L.: Fr.) Pil., Ustulina deusta (Hoffm.: Fr.) Lind, and many others contain fungal populations, in which individuals of the same or different species grow side by side, each occupying a restricted, well-delimited area and fruiting on an adjacent surface only (cf. Rayner \& Boddy 1988). The 
latter type of fungi must be common among secondary decayers and among saprophytes, which colonize wood in its final stage of decay. If the growth habit of each species was known, it would be easier to calculate the numbers of individuals on the basis of the fruit bodies. Such information would also allow a more reliable statistical estimate of the constancy with which each species fruits. However, such a study can only be made in a very restricted area and falls outside the scope of the present work.

\section{A note on distribution}

Eriksson and Strid (1969) introduced the term "taiga species" for fungi having a special northern distributional pattern. Taiga literally means the northern coniferous forest, or the Boreal zone, perhaps excluding its most oceanic sections (i.e., in Europe excluding Iceland, northern Scotland and the westernmost coastal strip of Norway, which lie outside the natural range of spruce; see Ahti et al. 1968). Hence, by definition, the "taiga species" would be species found throughout the Boreal continental and indifferent areas, but absent or rare in Temperate Central Europe, or found there in montane forests only. If understood in this way, true "taiga species" would be, for instance, Gloiodon strigosus (Swartz: Fr.) Karst., Phellinus lundellii Niemelä, Polyporus tubaeformis Karst., Scutiger syringae Parm. and Trametes ochracea (Pers.) Gilb. \& Ryv. This was not the meaning in which the term was used by Eriksson and Strid (1969) and other authors when they wrote of fungi found in Fennoscandia only in the extreme northeastern forest areas. Examples of such species in Eriksson and Strid's (1969) paper are Amylocystis lapponica (Rom.) Sing., Laurilia sulcata (Burt.) Pouz. and Phlebia centrifuga Karst.

We discourage the use of the term "taiga species" in the above, special sense. It would be more appro-

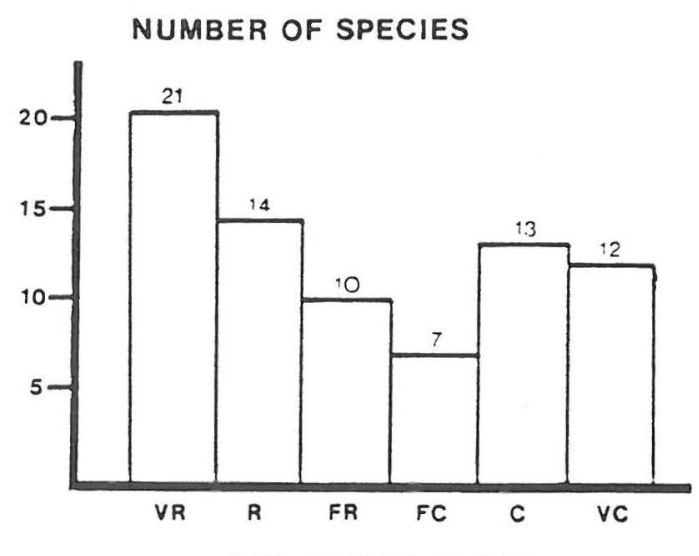

ABUNDANCE CLASS

Fig. 1. The distribution of the polypore species among the different abundance classes in northeastern Finland. VR = very rare, $\mathrm{R}=$ rare, $\mathrm{FR}=$ fairly rare, $\mathrm{FC}=$ fairly common, $\mathrm{C}=$ common, $\mathrm{VC}=$ very common.

priate to call such a distributional pattern boreo-continental. Fungi (and other organisms) that do not even occur in the Middle Boreal zone could be called "strictly boreo-continental", and those whose distribution extends farther south could be "strongly" or "slightly boreo-continental". An example of the boreo-continental distribution among vascular plants would be provided by the Siberian Spruce (Picea abies subsp. obovata) (see map in Hämet-Ahti et al. 1989: 51); while its distribution is clearly Northern Boreal in western, slightly oceanic areas (e.g., Sweden, Finland, the Kola Peninsula), it may extend to more southern latitudes in the continental inner parts of Eurosiberia. 


\section{Check list}

In the following an alphabetical list is given of all polypore species found in the Värio Strict Nature Reserve, the Urho Kekkonen National Park and the Tuntsa forest-fire area during 1987-1989. After each name the range of hosts is presented (with \% frequency), followed by the total number of observations and the estimate of general abundance. $1=$ Alnus incana subsp. kolaënsis; $2=$ Betula pubescens subsp. czerepanovii $+B$. sp.; $3=$ Picea abies subsp. obovata; $4=$ Pinus sylvestris; $5=$ Populus tremula; $6=$ Salix caprea $\mathbf{7}=$ Salix (other than $S$. caprea); $8=$ Sorbus aucuparia; $\mathbf{n}=$ total number of observations. $\mathbf{v r}=1-2 ; \mathbf{r}=3-10 ; \mathbf{f r}=11-20 ;$ fc $=21-30 ; c=31-80 ;$ vc $=$ over 80 observations. Species marked with an asterisk $\left.{ }^{*}\right)$ form fruit bodies on the ground and the names given as hosts of these species indicate only the predominant tree species at the growth sites. Species which are classified as threatened in Finland are printed in bold face. There are evidently one unnamed species of Antrodia and one of Antrodiella, which will be discussed soon in forthcoming papers.

Species

$\begin{array}{llllllllll}1 & 2 & 3 & 4 & 5 & 6 & 7 & 8 & \mathrm{n} & \mathrm{ab} .\end{array}$

Amylocystis lapponica (Rom.) Sing. (Note 1)

Amyloporia crassa (Karst.) Bond. \& Sing. (Note 2)

A. xantha (Fr.: Fr.) Bond. \& Sing.

Anomoporia myceliosa (Peck) Pouz. (Note 3)

Antrodia albobrunnea (Rom.) Ryv. (Note 4)

A. pulvinascens (Pil.) Niemelä (Note 5)

A. serialis (Fr.) Donk

A. sinuosa (Fr.) Karst.

A. sp. 1 (Note 6)

Antrodiella semisupina (Berk. \& Curt.) Ryv. (Note 7)

A. sp. 1 (Note 8)

Aporpium caryae (Schw.) Teix. \& Rogers (Note 9)

Bjerkandera adusta (Willd.: Fr.) Karst.

Boletopsis grisea (Peck) Bond. \& Sing.*

Ceriporia reticulata (Hoffm.: Fr.) Dom. (Note 10)

Ceriporiopsis aneirina (Somm.) Donk

C. resinascens (Rom.) Dom.

Cerrena unicolor (Bull.: Fr.) Murr.

Climacocystis borealis (Fr.) Kotl. \& Pouz.

Coltricia perennis (L.: Fr.) Murr.*

Daedaleopsis septentrionalis (Karst.) Niemelä (Note 11)100

Dichomitus squalens (Karst.) Reid (Note 12)

Diplomitoporus crustulinus (Bres.) Dom. (Note 13)

Fomes fomentarius (L.: Fr.) Fr.

Fomitopsis pinicola (Sw.: Fr.) Karst.

F. rosea (Alb. \& Schw.: Fr.) Karst. (Note 14)

Fuscoporia viticola (Schw. ex Fr.) Murr.

Gelatoporia pannocincta (Rom.) Niemelä (Note 15)

G. subvermispora (Pil.) Niemelä (Note 16)

Gloeophyllum protractum (Fr.) Imaz. (Note 17)

G. sepiarium (Wulf.: Fr.) Karst.

Gloeoporus dichrous (Fr.: Fr.) Bres.

Hapalopilus rutilans (Pers.: Fr.) Karst.

Inonotus obliquus (Pers.: Fr.) Pil.

Junghuhnia luteoalba (Karst.) Ryv.

Lasiochlaena benzoina (Wahl.) Pouz.

Leptoporus mollis (Pers.: Fr.) Quél. (Note 18)

Meruliopsis taxicola (Pers.) Bond. (Note 19)

Oligoporus sericeomollis (Rom.) Pouz.

- $\quad$ - 973 - 3 - $\quad$ - $89 \mathrm{vc}$

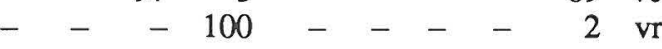

$-\quad 592-3-\quad-130 \mathrm{vc}$

- $\quad 5050$ - $\quad$ - $2 \mathrm{vr}$

- $\quad-100-\ldots$ - $35 \mathrm{c}$

$-\quad-\quad-100 \quad-\quad-1$ vr

$-\quad 100-\quad-\quad-56 \mathrm{c}$

- $\quad 991-\ldots$ - $\quad$ - $35 \mathrm{c}$

$-\quad-\quad-100 \quad-\quad \ldots \quad-16 \mathrm{fr}$

$-100-1-\quad-\quad-\quad-\quad 1$ vr

- $\quad-6139-618$ - 618 fr

$-100-\ldots+\ldots$ v

$-100-\quad-\quad-\quad-1 \mathrm{vr}$

$-\quad-100--\quad-\quad 9$ r

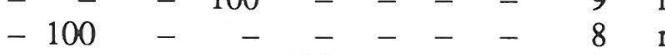

$-\quad-\quad-100-\ldots$ vr

$-\quad-\quad-50-\quad-502 \mathrm{vr}$

$-100-\quad-\quad-\quad-\quad-62 \mathrm{c}$

$-\quad-100-\quad-\quad-26 \mathrm{fc}$

$-\quad-\quad 1981-\ldots+101 \mathrm{vc}$

$00-\quad-\quad-\quad-\quad-14 \mathrm{fr}$

- $\quad-100-\quad-\quad-1$ vr

$-100$

$-100-$

$-192$

$-\quad 100$

$-\quad-57$

$-100-$

$-\quad-100$

$-\quad-36$

$-\quad-93$

$-100-$

$-33-$

$595-$

$-\quad-100$

$-\quad 88$

$-\quad-100$

- $\quad-97$

$-\quad 19$

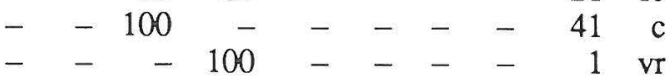

Phaeolus schweinitzii (Fr.) Pat. 


\begin{tabular}{|c|c|c|c|c|c|c|c|c|c|}
\hline Species & 2 & 3 & 4 & 5 & 6 & 7 & 8 & & ab. \\
\hline Phellinidium ferrugineofuscum (Karst.) Fiass. \& Niemelä & $1-$ & 98 & 2 & - & - & - & - & 49 & c \\
\hline Phellinus igniarius (L.: Fr.) Quél. & -100 & - & - & - & - & - & - & 94 & $\mathrm{vc}$ \\
\hline P. laevigatus (Karst.) Bourd. \& Galz. (Note 20) & -100 & - & - & - & - & - & - & 45 & $\mathrm{c}$ \\
\hline$P$. lundellii Niemelä & 1189 & - & - & - & - & - & - & 45 & $\mathrm{c}$ \\
\hline P. nigrolimitatus (Rom.) Bourd. \& Galz. & - & 99 & 1 & - & - & - & - & 86 & $\mathrm{vc}$ \\
\hline P. tremulae (Bond.) Bond. \& Borisov & - & - & - & 100 & - & - & - & 36 & c \\
\hline Piloporia sajanensis (Parm.) Niemelä (Note 21) & - & 100 & - & - & - & - & - & 2 & vr \\
\hline Piptoporus betulinus (Bull.: Fr.) Karst. & -100 & - & _ & - & - & - & - & 68 & $\mathrm{c}$ \\
\hline Polyporus brumalis (Pers.: Fr.) Fr. & -40 & - & - & - & 50 & - & 10 & 10 & $\mathrm{r}$ \\
\hline P. leptocephalus Jacq.: Fr. & - & - & - & & 00 & - & - & 2 & vr \\
\hline Porodaedalea chrysoloma (Fr.) Fiass. \& Niemelä & - & 100 & - & - & - & - & - & 97 & vc \\
\hline P. conchata (Pers.: Fr.) Fiass. \& Niemelä & - & - & - & 100 & - & - & - & 12 & fr \\
\hline P. pini (Brot.: Fr.) Murr. & - & - & 100 & - & - & - & - & 5 & 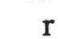 \\
\hline Postia caesia (Schrad.: Fr.) Karst. & 8 & 92 & - & - & - & - & - & 12 & \\
\hline 3erk. \& Br.) Jül. (Note 22) & - & 5 & 95 & - & - & - & - & 19 & \\
\hline P. lowei (Pil.) & - & - & 100 & - & - & - & - & 18 & \\
\hline (Fr.) Larsen \& Lombard (Note 24) & - & 50 & 50 & - & - & - & - & 2 & $\mathrm{vr}$ \\
\hline Pycnoporus cinnabarinus (Jacq.: Fr.) Karst. & -100 & - & - & - & - & - & - & 2 & \\
\hline Scutiger confluens (Alb. \& Schw.: Fr.) Bond. \& Sing.* & - & 100 & - & - & - & - & - & 1 & vr \\
\hline S. ovinus (Schaeff.: Fr.) Murr.* & - & 100 & - & - & - & - & - & 5 & \\
\hline S. subrubescens Murr.* (Note 25) & - & - & 100 & - & - & - & - & 1 & $\mathrm{vr}$ \\
\hline Sistotrema muscicola (Pers.) Lundell (Note 26) & - & - & 100 & - & - & - & - & 1 & vr \\
\hline Skeletocutis jelicii Tor & - & - & 100 & - & - & - & - & 1 & $\mathrm{vr}$ \\
\hline S. lenis (Kars & - & - & 100 & - & - & - & - & 17 & \\
\hline S. odora (Sacc.) Ginn & - & 100 & - & - & - & - & - & 32 & c \\
\hline S. stellae (Pil.) Kelle & - & 100 & - & - & - & - & - & 5 & \\
\hline S. subincarnata (Peck) Keller & - & 43 & 57 & - & - & - & - & 7 & \\
\hline Trametes hirsuta (Wulf.: Fr.) Pil. & -100 & - & - & - & - & - & - & 1 & $\mathrm{vr}$ \\
\hline T. ochracea (Schaeff.) Gilb. \& Ryv. & -68 & 4 & - & 20 & 4 & 4 & - & 25 & fc \\
\hline T. pubescens (Schum.: Fr.) Pil. & -100 & - & - & - & - & - & - & 6 & \\
\hline Trechispora mollusca (Pers.: Fr.) Lib. (Note 31) & -100 & - & - & - & - & - & - & 2 & $\mathrm{vr}$ \\
\hline Trichaptum abietinum (Pers.: Fr.) Ryv. & - & 89 & 11 & - & - & - & - & 133 & $\mathrm{vc}$ \\
\hline T. hollii (J.C. Schmidt) Kreisel & - & 20 & 80 & - & - & - & _- & 25 & fc \\
\hline T. laricinum (Karst.) Ryv. (Note 32 ) & - & 78 & 22 & - & - & - & - & 46 & c \\
\hline Tyromyces chioneus (Fr.) Karst. & -100 & - & - & - & - & - & - & 25 & $\mathrm{fc}$ \\
\hline T. kmetii (Bres.) Bond. \& Sing. (Note 33) & -100 & - & - & - & - & - & _ & 7 & \\
\hline
\end{tabular}

\section{Notes on selected species}

\section{Amylocystis lapponica}

Amylocystis lapponica (Fig. 2) is one of the most typical elements of the wood-rotting fungi in old, spruce-dominated virgin forests in northeastern Finland. It is very common in the study area and one of the basic saprophytic members in the fungal communities of fallen trunks of the Siberian Spruce (Picea abies subsp. obovata). On spruce it seems always to grow together with Fomitopsis rosea. The distribution is concentrated in the northeastern parts of Eu- rope and northern parts of the Soviet Union. Its distribution type is strongly boreo-continental ("taiga species" in the sense of Eriksson \& Strid 1969). The fruiting of the fungus varies greatly from year to year, which may be the main reason for deviating earlier opinions (Eriksson 1958, Eriksson \& Strid 1969) of the scarcity of the species. The present three finds on pine (Pinus sylvestris) are the first reported on this host in Fennoscandia. Amylocystis lapponica is classified as a threatened (rare) species in Sweden (Ingelög et al. 1984), but not in Finland. 


\section{Amyloporia crassa}

We obtained this very rare fungus twice. Both collections (7522:613; TR 323, 7520:610; PR 1910) are from large, fallen and fairly strongly decayed, decorticated trunks of pine. The former trunk was, in addition, partly charred. In both cases the sites were microclimatically humid with a thick layer of dwarf shrubs in otherwise dry forest of the EMT site type (see Renvall et al. 1991). The species is classified as endangered in Sweden (Ingelög et al. 1984) and according to a revised list (unpublished; see page 27) is considered vulnerable in Finland.

\section{Anomoporia myceliosa}

This very rare saprophyte in Europe (Niemelä 1978a) is classified as vulnerable in Finland (Rassi et al. 1986, Rassi \& Väisänen 1987): there are only 4 earlier finds from the country. The collections made in the study area (7520:609; PR 464, 1066, 1067, 1949) derive from a single site, where the fungus was growing on a partly soot-blackened and fairly strongly decayed piece of board (evidently spruce), and on a dried and decorticated branch of pine lying next to it. This is the third Finnish find on processed wood. The species seems to demand a stable and moist (not wet) microclimate: the site was a humid depression in a dry pine forest of the EMT site type. The branch of pine also harboured Antrodia albobrunnea. Anomoporia myceliosa is probably a weak competitor and seems to depend on the constant presence of certain commoner wood-inhabiting species. It should have countless suitable potential habitats, but to our knowledge it is very rare everywhere.

\section{Antrodia albobrunnea}

In addition to Amyloporia xantha, Antrodia albobrunnea is one of the most characteristic polypores in the pine-dominated virgin forests of northern Finland. In the study area it chiefly favours forests of the EMT site type, being a fairly common saprophyte and often growing on strongly decayed, fallen trunks of pine. The fruit bodies almost invariably develop on the under-sides of trunks, very near to the ground, and the fungus seems to need a stable and moist microclimate. In southern Finland, in particular, the species is very rare, suffering from forestry, and it has therefore been classified as in need of monitoring, rare (unpublished).

\section{Antrodia pulvinascens}

Niemelä (1978b, 1985a) summarized the taxonomy and habitat ecology of this rare fungus in Fennoscandia. We found it once (7520:609; PR 1383, 1803) in the study area and the find is the northernmost in Fennoscandia. The fruit bodies grew on a fallen, partly decorticated and fairly large trunk of Populus tremula. The same trunk also harboured Ceriporiopsis resinascens. The site was luxuriant and microclimatically moist grass-herb forest composed of $\mathrm{Popu-}$ lus tremula, Betula pubescens, Sorbus aucuparia and Salix caprea.

\section{Antrodia sp. 1}

An unidentified effused-reflexed or resupinate, dimitic polypore was collected 16 times. One specimen has earlier been found by $T$. Niemelä and one by Heikki Kotiranta (pers. comm.) and the material will be described in detail on a later occasion.

\section{Antrodiella semisupina}

We obtained a single find (7559:569; PR 1362) of this species. It was growing typically on a dead standing trunk of birch (Betula pubescens) extensively decayed by Fomes fomentarius, and on some dead fruit bodies of the latter species. The habitat was wet grass-herb forest, composed predominantly of spruce and birch, beside the River Jaurujoki, and was also the only locality of Bjerkandera adusta in the study area.

\section{Antrodiella sp. 1}

The genus Antrodiella, recently described by Ryvarden and Johansen (1980), is taxonomically difficult and apparently rather poorly known. It seems to include some undescribed species in Fennoscandia, which are filed in herbaria under Antrodiella romellii (Donk) Niemelä and A. semisupina. In our opinion there is one undescribed species occurring on conifers in the study area.

Specimens were found on decorticated parts of partly corticated trunks of spruce and pine. The fruit bodies grow often near or sometimes on dead fruit bodies of some species of Trichaptum. The host trees have sometimes been decayed primarily also by $\mathrm{FO}^{-}$ mitopsis pinicola. Species of the genus Antrodiella are known to have significant relationships with other wood-rotting polypores (cf. Jahn 1967, Niemelä 1988). 

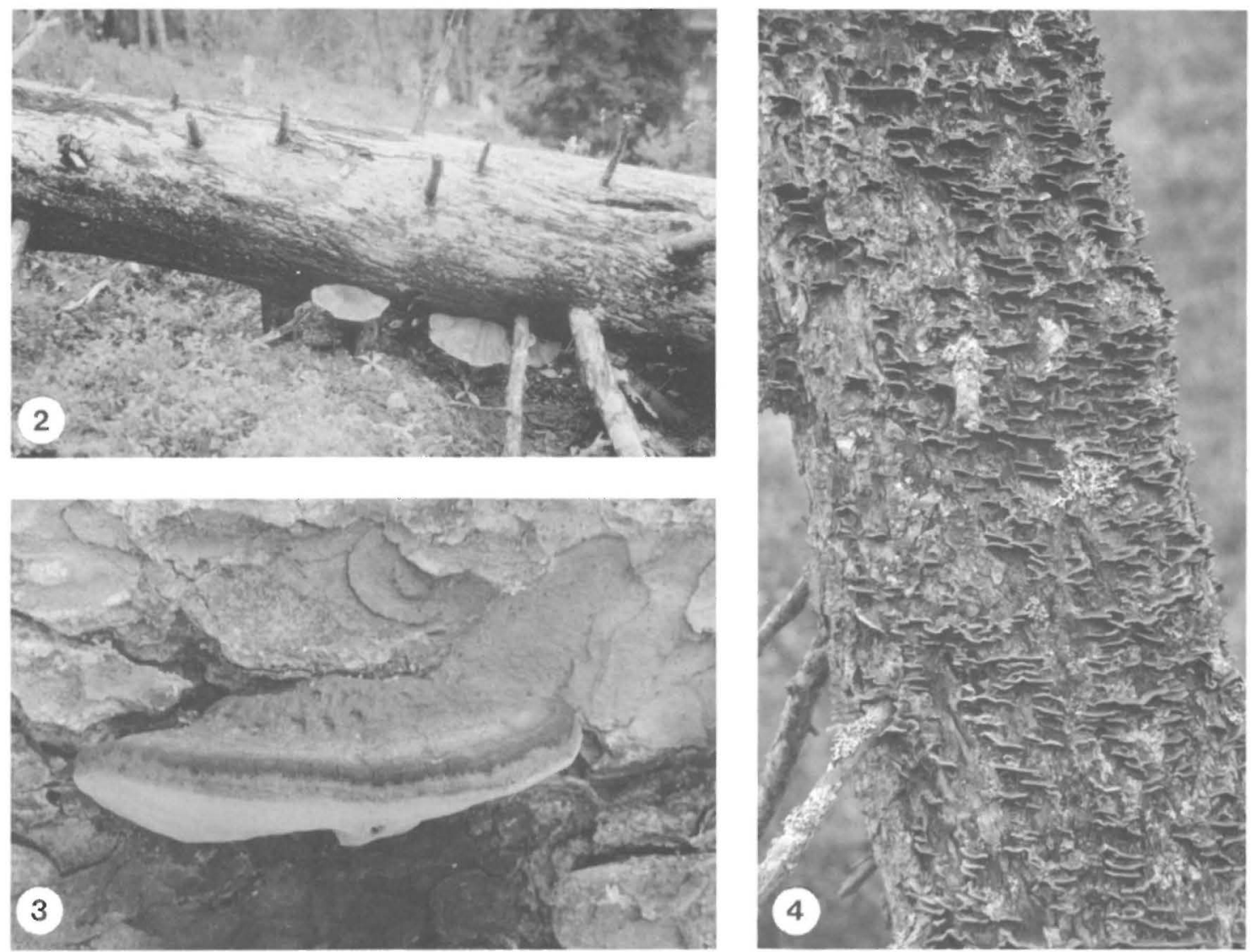

4

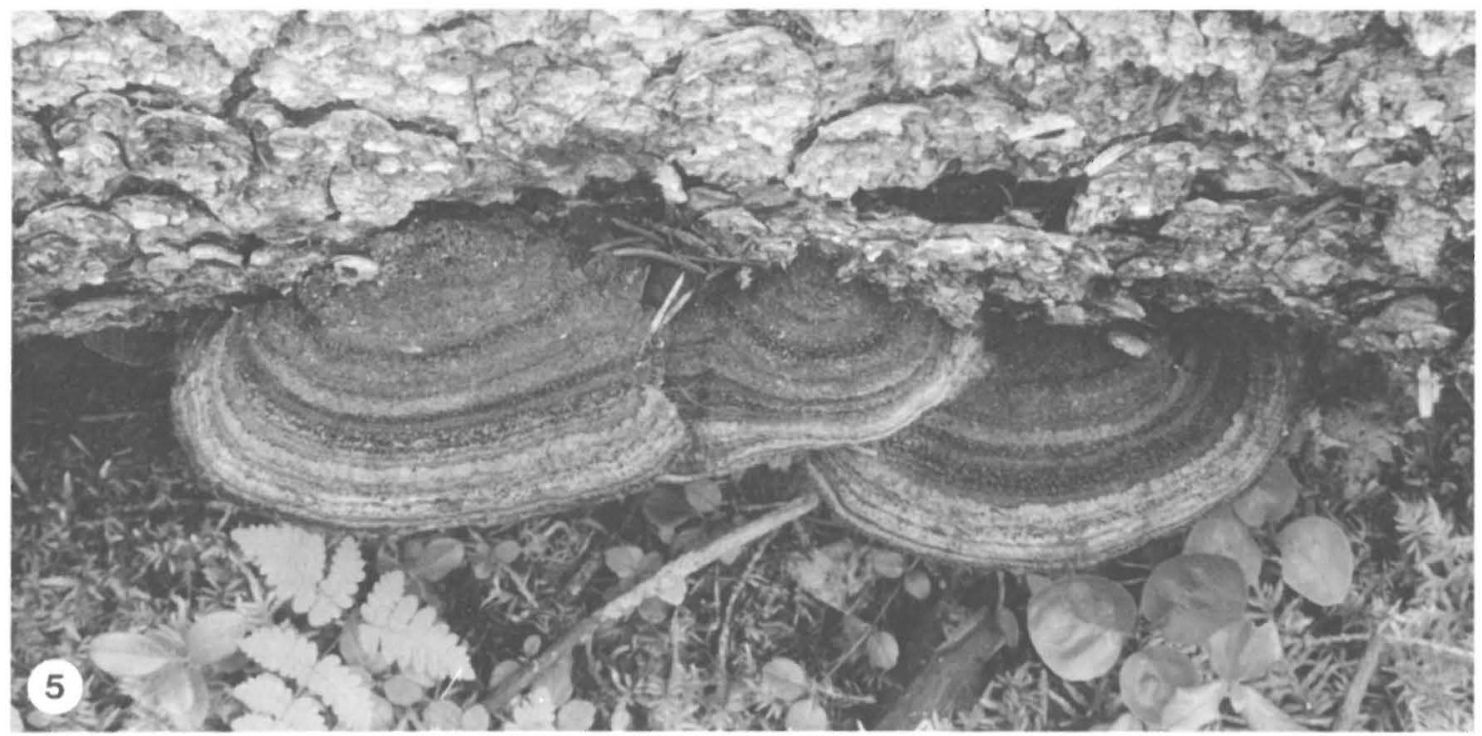

Figs. 2-5. Common and abundant decayers of the Siberian Spruce in Finnish Lapland. - 2: Amylocystis lapponica (PR 954, H). 3: Fomitopsis rosea (PR 1946, H). - 4: Trichaptum laricinum. - 5: Porodaedalea chrysoloma (PR 1917, H., P.R.). 


\section{Aporpium caryae}

The species was found twice (7520:609; PR 467 and 7520:605; PR 1150) in the study area. Both collections derive from a saw-cut log or trunk of birch. Niemelä (1978a) reports that $A$. caryae often occurs together with other wood-rotting fungi, but here such an association could not be observed. It is classified as a threatened (in need of monitoring, rare) species in Finland (unpublished).

\section{Ceriporia reticulata}

All eight records of Ceriporia reticulata were made in a single wet site (7522:609), on a lush meadow inundated by spring flooding. The species was growing only on fallen and strongly decayed trunks of birch. It seems to have an effective dispersal ability, but a fairly narrow ecological amplitude. Although there are thousands of fallen, decaying trunks of birch in the study area, only one growth site seemed to satisfy this species.

\section{Daedaleopsis septentrionalis}

Daedaleopsis septentrionalis occurs only in the Northern Boreal vegetation zone (Niemelä 1982a, 1988), as delimited by Ahti et al. (1968), and may represent the boreo-continental distribution type. It is one of the most typical saprophytic polypores in uphill woodlands consisting chiefly of the Mountain Birch (Betula pubescens subsp. czerepanovii). It is fairly rare in the study area and tends to grow without any associate fruiting polypore.

\section{Dichomitus squalens}

In Fennoscandia Dichomitus squalens is a very rare saprophyte or saproparasite of spruce and pine and prefers decorticated trunks (Ryvarden 1976). It is evidently a weak competitor there and generally persists and forms fruit bodies in fairly dry and open habitats. We collected it only once: on a fallen, still corticated trunk of spruce in a fairly moist sprucedominated forest. Overholts (1953) considers $D$. squalens (as Polyporus anceps Peck) to be a parasitic species in North America, and Niemelä (1985b) reports similar observations from Northern Quebec in Canada.

\section{Diplomitoporus crustulinus}

The species is a very rare saprophyte, which has been classified as an endangered species in Sweden (Ingelög et al. 1984) and will be included as vulnerable in a revised list of the threatened fungi in Finland (unpublished). It grows in North Europe, being restricted to climatically continental regions, with virgin forests dominated by spruce (Ryvarden 1976). We found it three times in the study area. The sites are microclimatically moist, often in paludified spruce forest beside brooks. It is evidently a weak competitor but a rapid decayer, and needs a host that is still corticated, has fallen in a healthy state, and bears almost no other wood-rotting fungi.

\section{Fomitopsis rosea}

Fomitopsis rosea (Fig. 3) is the most characteristic polypore in the spruce-dominated virgin forests of northern Fennoscandia, and one of the most common and abundant species in the study area. It is a saprophyte and in the study area grows only on fallen trunks of spruce: not a single find was made on stumps. It seems to need a fairly stable and moist microclimate, because it is rare in dry habitats. It is classified as a threatened (in need of monitoring) species in Sweden (Ingelög et al. 1984).

Fomitopsis rosea seems to be one of the most important primary decomposers of healthy trunks of spruce which have been blown down in storms. It evidently competes well with saproparasitic species, because the latter were rarely observed on trunks inhabited by $F$. rosea, an exception being $F$. pinicola. According to Kotiranta and Niemelä (1981) F. rosea usually grows on trunks of spruce which have been killed by $F$. pinicola, and in our study area also, $F$. pinicola is evidently the most important parasitic species preceding $F$. rosea. $F$. rosea is the foremost competitor of $F$. pinicola and other aggressive decayers in the wood-rotting fungal communities of fallen spruce trunks, and surely has a strong influence on the eco-pathological balance of such communities.

Fomitopsis rosea is associated with certain other abundant species, and is seldom found alone, without associates. It is one of the boreo-continental species, and it seems that very many of the wood-inhabiting fungi of the same distribution type depend either directly or indirectly on its occurrence. It grows especially often together with Amylocystis lapponica and Phlebia centrifuga, as was clearly observed in the study area. Other frequent associates are Antrodia serialis, Columnocystis abietina (Fr.) Pouz., Phelli- 
nus nigrolimitatus, Phellinidium ferrugineofuscum and Skeletocutis odora.

\section{Gelatoporia pannocincta}

This is a rare species in Fennoscandia, and favours large fallen trunks of Populus tremula, but in northern Finland it usually grows on the Mountain Birch (Niemelä 1985a). Rassi et al. (1986) classified it as threatened (in need of monitoring, declining) in Finland. We made two finds (75198:6052; PR 980, 7513: 613; PR 1162), on strongly decayed, fallen trunks of the Mountain Birch. One trunk also harboured Tyromyces chioneus and the other was evidently decayed primarily by Phellinus igniarius. Though there seem to be many suitable growing sites, the species is very rare, probably growing exclusively on fairly strongly decayed hardwood in microclimatically moist and stable habitats. One reason for the rarity of the fungus can be found among the associated species. Gelatoporia pannocincta seems to be a weak decayer and also a weak competitor. Its survival may depend not only on the climatic conditions, but also on the presence of certain commoner wood-inhabiting species. In northeastern Finland important associate polypores may be Fomes fomentarius, Tyromyces chioneus or some Phellinus species.

\section{Gelatoporia subvermispora}

This very rare species was found once (75208:6100; PR 1913). The fruit body grew inside a cavity in a strongly decayed but still partly corticated, fallen trunk of spruce. The habitat was spruce-dominated forest on dry rocky ground in a brook ravine. In Fennoscandia Gelatoporia subvermispora is known only from Finland and our find is the northernmost one. According to Niemelä (1985a), its general distribution is not particularly northern.

\section{Gloeophyllum protractum}

This northern member of the genus Gloeophyllum is a fairly rare saprophyte, which inhabits fallen trunks of both pine and spruce in the study area. G. protractum (Fig. 6) clearly benefits from and even depends on forest fires and a supply of charred wood: $80 \%$ of the observations on spruce and $72 \%$ on pine were on fallen trunks at least partly affected by fire. The sites are usually open, sunny places in dry pine woodlands. The observations on spruce mostly derive from the forest-fire area of Tuntsa. On pine it was mostly growing alone or it shared the trunk with Amyloporia xantha. Its distribution is boreo-continental.

\section{Leptoporus mollis}

This fairly rare saprophyte or possibly weak parasite grows on fallen trunks and stumps of spruce in the study area. It prefers corticated trunks, most of those chosen having been killed by Onnia leporina or by Porodaedalea chrysoloma. Leptoporus mollis was never observed on trunks killed by Fomitopsis pinico$l a$, but it often appears together with Meruliopsis taxicola and Phlebia centrifuga. The fruit bodies of these species often grow side by side. Once a fruit body of L. mollis was found growing on a dead fruit body of $M$. taxicola. Other common associate species are $F O$ mitopsis rosea and Gloeophyllum sepiarium. L. mollis was found five times (29\% of the observations) without any evidence of other wood-rotting species on the same host.

\section{Meruliopsis taxicola}

Meruliopsis taxicola turned out to be a fairly common saprophyte in the study area, growing primarily on fallen but corticated trunks of spruce. We collected it once on a fallen trunk of pine. Its fruit bodies often decorate crowns and branches of fallen trees. The habitats are usually very moist, often beside brooks or swampy areas. It grows particularly often with Phlebia centrifuga. Other common associates are Fomitopsis rosea, Leptoporus mollis, Phellinidium ferrugineofuscum and Skeletocutis odora. M. taxicola was also observed alone (19\% of the observations).

\section{Phellinus laevigatus}

Characteristic hosts for this saprophyte are rather recently fallen and still corticated trunks of birch in spruce forests (cf. Niemelä 1972). In the study area the species seems to have a dual growing site ecology, because it occurs in mesic spruce forests but also in dry woodlands composed of the Mountain Birch near the tops of the fjelds. There it grows on dead but still standing trunks, 1.5 to 3 metres above the ground. It seems to be the only polypore species which can survive in the dry woodlands of upper fjelds near the timberline, at an approximate altitude of 400 metres.

\section{Piloporia sajanensis}

Piloporia sajanensis is a very rare conifer-rotting polypore which has previously been recorded only six times: there are three collections from the Soviet Union, two from Sweden and one from Finland (Strid 1981, Niemelä 1982b, Ryvarden 1986). We found it twice on spruce (75221:6097 TR 583, PR 

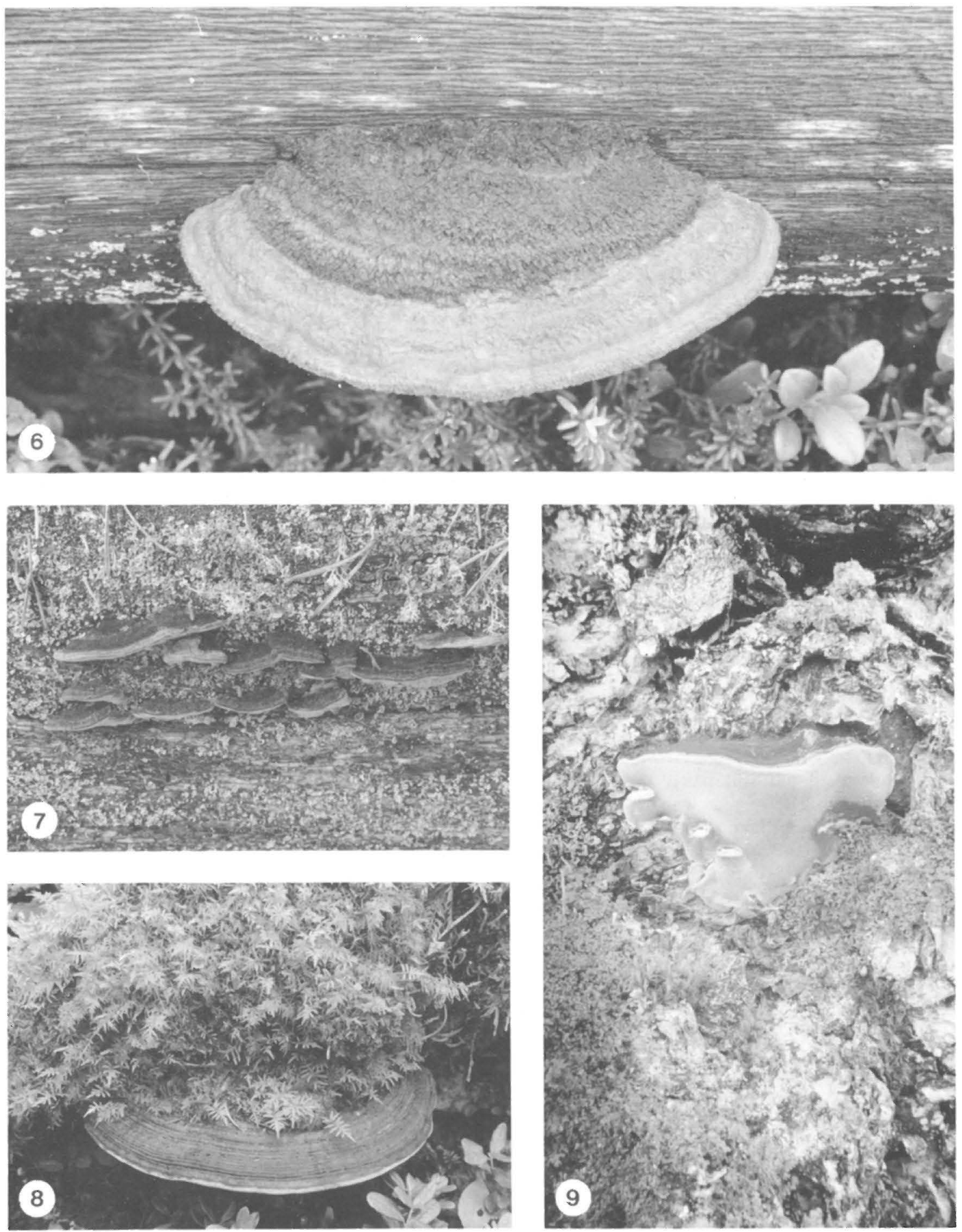

Figs. 6-9. - 6: Gloeophyllum protractum, a fairly rare saprophyte of pine and spruce in northem Finland(PR 1906 H, P.R.). - 7: Fuscoporia viticola on a fallen trunk of pine (PR 1919, H, P.R.). - 8: Phellinus igniarius s. lat., one of the most abundant polypores on birch (PR 1863, H, P.R.). - 9: Phellinus lundellii, a common saprophyte of birch in the study area (PR 1832, H, P.R.). 
1885; 75186:6097 PR 1930) in two separate localities: on a fallen rotten trunk and on the separate branch of a fallen trunk. The two localities are situated beside a brook, which ensures their rather stable moisture. In the former find, the trunk was primarily strongly decayed by Trichaptum laricinum, and the same succession was reported by Niemelä (1982b). The log also harboured Phellinus nigrolimitatus. The trunk to which the branch of the latter collection had belonged harboured characteristic boreo-continental species, Phellinus nigrolimitatus, Phlebia centrifuga and Skeletocutis odora. Our collections support Strid's (1981) suggestion that $P$. sajanensis is northern-boreal in its distribution, being concentrated in northeastern continental parts of Europe and northern or mountainous parts of the Soviet Union.

\section{Postia hibernica}

This easily overlooked polypore is a fairly rare saprophyte in the study area and grows typically on fallen, decorticated, dry trunks or branches of pine. We also found it once on a fallen trunk of spruce. Preferring very dry places in pine woodlands, it grows mostly alone, without any visible associate species. The fruit bodies of Postia hibernica are effused or effusedreflexed and very small, and the fruiting varies annually. All this makes it difficult to estimate the abundance of the species, which will be classified as threatened (in need of monitoring, rare) in Finland.

\section{Postia lowei}

Fallen, decorticated trunks of pine are the only hosts of this fairly rare saprophyte in the study area. The fruiting varies greatly according to the year. The species seems to prefer fallen, medium-sized trunks and apparently often grows without any associates. The commonest co-occurring fungus is Amyloporia xantha. $P$. lowe $i$ avoids the driest pine woodlands, preferring relatively stable moisture and shade, and in the study area it clearly favours pine forests of the EMT site type. It is included as in need of monitoring and rare in a revised list of threatened fungi in Finland (unpublished).

\section{Postia placenta}

In North Europe Postia placenta is a rare saprophyte of old virgin forests and selects large and decorticated trunks as its substrate (Eriksson 1958, Ryvarden 1978, Niemelä 1988). We found it twice in the study area: once (75201:6105; PR 406, 960) it grew on a large, fallen, rotten and decorticated trunk of spruce in wet, partly paludified spruce forest beside a brook. The same trunk was inhabited by Phellinus nigrolimitatus and Fomitopsis rosea, though the fruit bodies of the latter were dead. The other specimen (7560: 570; TR 414) grew on a large, fallen and decorticated trunk of pine in a fairly dry pine forest without any associate polypores. The species is known to be very variable in its morphology and colour, and the name Poria monticola Murrill is often used in North America for a bleached variety. Two of our specimens were pink-coloured while the third was sordid brownish with a reddish tint.

\section{Scutiger subrubescens}

Our single find $(7560: 571$; PR 1343, 1367) of this poorly known, evidently rare species is the northernmost reported in Fennoscandia. It was growing in a dry pine-dominated forest of the EMT site type, on a north-facing slope. It seems to prefer dry stands of pine. Adjacent fungi were Bankera fuligineoalba (Schmidt: Fr.) Pouz. and Coltricia perennis.

\section{Sistotrema muscicola}

A poroid form of this variable saprophyte was found once (PR 556) on a fallen, strongly decayed and charred stump of pine. Eriksson et al. (1984) reported the species as rare in North Europe and the poroid form must be rare in northeastern Finland.

\section{Skeletocutis jelicii}

Kotiranta (1984) summarized the characters and distribution of this European rarity. We found it once (7521:610; PR 1805), on a fallen, thin, strongly decayed trunk of pine in a forest of the EMT site type. Our find is the fourth from Finland. Elsewhere in Europe, the species has been reported, according to Kotiranta (1984), only once from Yugoslavia and the European distribution seems to have a northeastern emphasis. It is classified as threatened (in need of monitoring, rare) in Finland (Rassi et al. 1986).

\section{Skeletocutis lenis (Karst.) Niemelä n. comb.}

Physisporus lenis Karst., in Rabenhorst \& Winter, Fungi Eur. Extraeur. 16: 3527, 1886 (holotype H, see Lowe 1956).

Good descriptions of the species have been published by Eriksson (1949) and Ryvarden (1976). It resembles the core species of Skeletocutis (S. amor- 
pha (Fr.) Kotl. \& Pouz., type of the genus; S. carneogrisea David) in many respects. All produce whiterot, are dimitic and bear fusiform cystidioles in the hymenium. A striking similarity is found in the spore shape: the spores are cylindrical and strongly bent, or lunate (Fig. 10), which is a rare character among polypores. In fact, young fruit bodies can be confused with Skeletocutis subincarnata, a similarity indicated by Eriksson (1949) and Ryvarden (1976). David (1982) reported this connection, too, and noted that both Skeletocutis species and S. lenis are tetrapolar. A deviating character observed by her is that while 'Skeletocutis typiques' show heterocytic nuclear behaviour, $S$. lenis has normal behaviour. However, $S$. subsphaerospora David shares this feature with $S$. lenis. So the major difference remaining between Skeletocutis in the sense of David (1982) and S. lenis is the evident lack of special sharp-pointed encrustations in the latter. However, such crystals are sometimes very rare in certain other species of the genus, and this absence may not be an exclusive character. Kotlaba and Pouzar (1990) transferred Leptoporus uralensis Pilát to Skeletocutis, although they failed to find the encrusted hyphae in it. (A parallel case can be found in the genus Fomitiporia Murr., or the Phellinus robustus (Karst.) Bourd. \& Galz. complex. Most species have setae in their hymenia, while a few lack them altogether. However, other characters clearly show that the group is homogeneous.)

Skeletocutis lenis is a fairly rare saprophyte, which in the study area grows only on fallen trunks of pine. It is one of the most characteristic species of the fungal communities on fallen, dried-up and extensively decayed trunks of pine. S. lenis is a strong decomposer of the latest successional stage, and causes soft and fragile white-rot. In the study area it often grows (50\% of the observations) alone. Antrodia albobrunnea was its commonest associate.

\section{Skeletocutis odora}

In the study area Skeletocutis odora is a fairly common saprophyte, which grows mainly on fallen but still corticated trunks of spruce. The species is classified as vulnerable in Sweden (Ingelög et al. 1984, as Incrustoporia tschulymica), but not in Finland. The fungus usually grows on trunks which have been killed and decayed by certain other polypores and it may be an important competitor of some economically harmful wood-rotting saproparasites. Typical saprophytic associates are Fomitopsis rosea, Phlebia centrifuga and Meruliopsis taxicola. Its distribution is slightly boreo-continental.

\section{Skeletocutis stellae}

This rare saprophyte of spruce grows almost exclusively on large, strongly decayed trunks, which harbour plenty of other wood-rotting fungi. In the study area most of its habitats are paludified thickets beside brooks, with spruce and willows intermixed. The species needs microclimatically stable and moist habitats to survive and its fruiting seems to start very slowly. However, we made a record in the Tuntsa Burn as well, where the species was growing in an open and rather dry area, but on a moist spot under the bark of a large, fallen spruce. It is classified as threatened (in need of monitoring) in Sweden (Ingelög et al. 1984) and will be included in a revised list of the threatened fungi in Finland (unpublished) as in need of monitoring and declining.

\section{Trechispora mollusca}

Both collections of Trechispora mollusca were made in the same permanently wet and lush meadow inundated by spring flooding. The species was growing on two fallen and strongly decayed birch trunks, on dead fruit bodies of Fomes fomentarius. Although the fruit bodies of this species are small and difficult to observe, it must be rare in the study area.

\section{Trichaptum laricinum}

Trichaptum laricinum is common on living and dead spruces in the study area. It grows on pine, too, but seldom. According to Eriksson (1958) and Niemelä (1988), it is an aggressive decomposer and killer of spruce in Lapland, whereas Norokorpi (1979) does not consider it a noteworthy pathogen of spruce. In our study area it seems to be economically harmful only on trunks of approximately medium or smaller diameter. Being a rapid invader, it grows mostly alone (Fig. 4). The commonest associates in the study area are Fomitopsis rosea, Gloeophyllum sepiarium and Trichaptum abietinum. Its distribution is boreocontinental.

\section{Tyromyces kmetii}

Tyromyces kmetii is a rare species in Europe (Ryvarden 1978, Kotiranta 1986), but in northern Finland it is less rare than elsewhere. The distribution in Finland is clearly concentrated in the extreme north (Kotiranta 1986). In the study area it grows only on the Mountain Birch (Betula pubescens subsp. czerepanovii). All earlier collections from Finland were made 

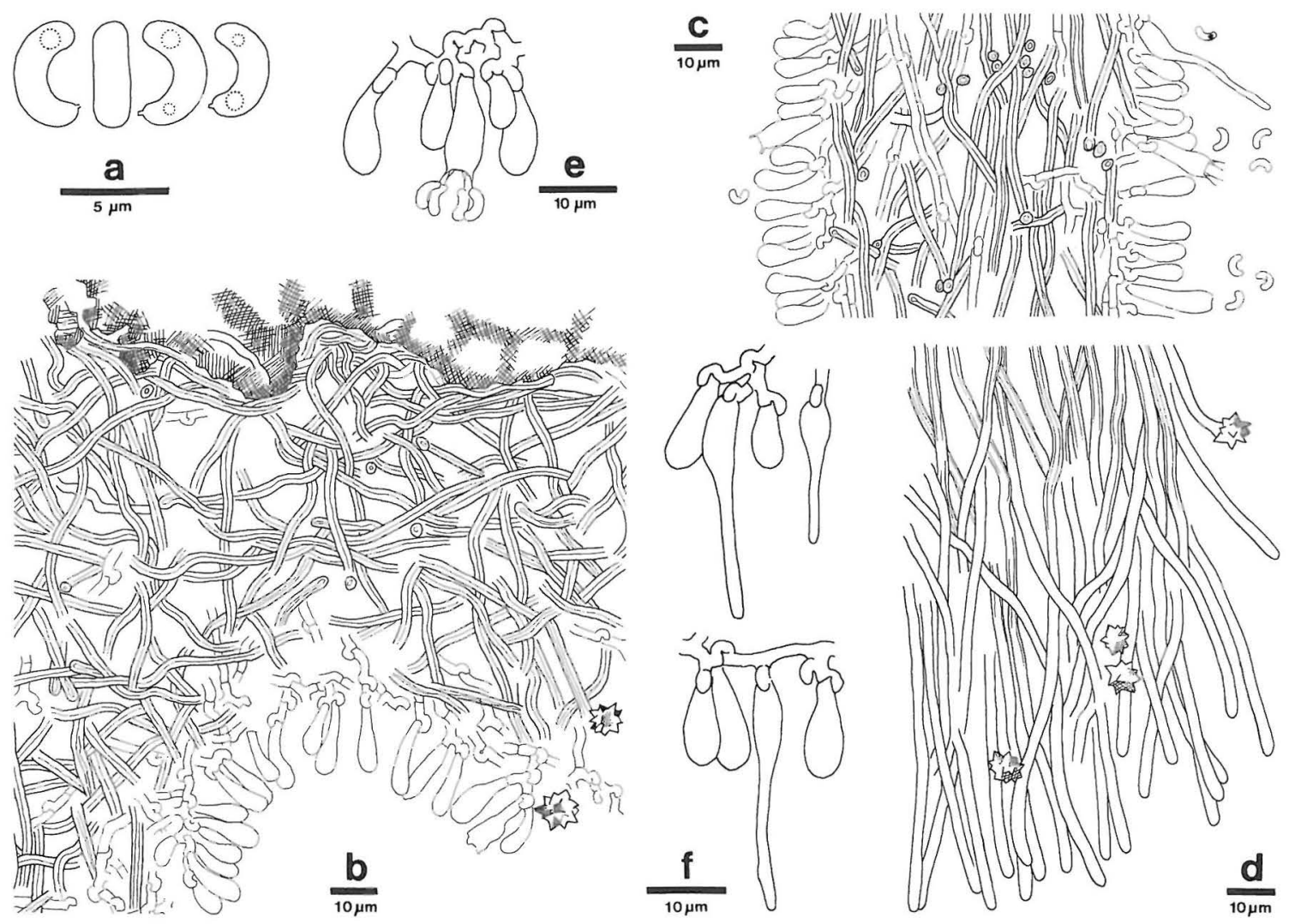

Fig. 10. Skeletocutis lenis. a) spores, b) subiculum in a vertical section, c) a section of dissepiment, d) dissepiment edge, e) basidia and basidioles, f) cystidioles. Drawn in Cotton Blue. Specimen PR 617, H.

on the same subspecies of birch (Kotiranta 1986). In the study area $T$. kmetii is rare and we found it only five times, despite the fact that there are thousands of decaying birches and apparently suitable sites.

The distribution is not known well enough to estimate the total climatic tolerance of the species, but its distribution type seems to be at least slightly boreocontinental. According to Ryvarden (1978), the distribution of Tyromyces kmetii in Scandinavia shows that it is a continental species. Kotiranta (1986) points out that the Swedish and Finnish habitats, which are in northern parts of the Northern Boreal vegetation zone, are climatically slightly continental or indifferent.
Some features of the polypore species composition in northeastern Finland

The polypore flora of the study area was found to resemble closely that in other parts of northern Fennoscandia (Eriksson 1958, Eriksson \& Strid 1969). We consider the number of species, 77 , to be rather high in view of the high elevation and northern location of our research area. In Finland altogether 186 polypore species have been recorded (Niemelä 1988).

Evidently partly because of climatic and other stresses, trees close to the timberline are often troubled by wood-rotting fungi. Niemelä (1985a) reported similar observations from eastern Canadian tim- 
berline forests. In the study area, particularly in the Värriö Strict Nature Reserve, the number of fruiting polypores is remarkably high. The main reason for this is the natural condition of the forests: they are characterized by a great number of fallen, decaying trunks and natural stumps, which offer plenty of substrates for wood-inhabiting fungi.

Polypores are the most important wood-rotting element, particularly on conifers, in the natural ecosystems of Northern Boreal timberline forests in Lapland. There are some wood-inhabiting species in the genera Armillaria, Hypholoma, Lentinellus, Lyophyllum, Panellus, Phyllotopsis and Tricholomopsis, but, judging by their fruit body production, polypores are the main primary decomposers of wood in the area. In the primary stage of decay, however, there are also some noteworthy corticiaceous fungi. In our study area the most important ones are Amylostereum chailletii (Fr.) Boid., Columnocystis abietina, Phlebia centrifuga and Stereum sanguinolentum (Alb. \& Schw.: Fr.) Fr. In addition, the genus Coniophora DC., as pointed out already by Eriksson (1958), includes significant primary decayers of conifers in Lapland.

We consider the diversity of polypore species to be directly comparable to the condition of the forests (e.g., seral stage, human impact). Together with certain insects, polypores are excellent bioindicators in estimating the conservational value of old forests. In forest evaluations it is useful first to study the abundance of polypores and their species spectrum, because the information on that group gives the quickest overall view of the condition of the forests to be compared, and offers a reliable reference for a closer analysis. The experience in Finland has clearly shown that if a forest harbours a high number of polypores and numerous inhabitants of virgin forest, the area surely also has a valuable insect fauna and if the forest is big enough - many rare birds.

\section{Yearly variation in the fruit body formation}

Strong yearly variation was noted in the fruit body emergence of certain polypore species in the study area. Annual changes may partly be due to internal fruiting cycles of the mycelia (Dr. Seppo Huhtinen, pers. comm.). However, the variability clearly depends on the weather of the growth season, both precipitation and temperature. The most strikingly fluctuating species on spruce are Amylocystis lapponica, Climacocystis borealis and to a lesser extent Leptoporus mollis and Skeletocutis odora. The two first-mentioned seemed to be rare or almost lacking in 1987, while they were abundant in the same area in 1988.
Polypores on pine having strong yearly variation are Postia hibernica and $P$. lowei. On birch, variable species are Daedaleopsis septentrionalis and Tyromyces chioneus. However, we feel that fruit body production is more constant in wood-inhabiting fungi than in mycorrhizal or litter-decomposing groups, although we cannot offer any quantitative data on this so far. All terrestrial polypores in the study area are also characterized by yearly changes in their fruiting; this concerns especially Boletopsis grisea and Coltricia perennis.

Annual variation in the fruit body formation seems to be especially strong in northern Finland, which makes it difficult to estimate the actual distributions or abundances of certain species. The variation did not seem to be confined to a certain host.

Polypores of spruce forests and birch-dominated woodlands

The flora of basidiomycetes of Boreal forests dominated by spruce is known to be especially rich (cf. Eriksson 1958). We found altogether 34 polypore species that grow on spruce, and the species are mostly different from those of drier pine forests. The most abundant species in spruce forests are Amylocystis lapponica, Fomitopsis pinicola, F. rosea, Gloeophyllum sepiarium, Phellinidium ferrugineofuscum, Phellinus nigrolimitatus, Porodaedalea chrysoloma (Fig. 5) and Trichaptum abietinum. Most of them are boreal or boreo-continental as are also Climacocystis borealis, Fuscoporia viticola, Leptoporus mollis, Onnia leporina, Skeletocutis odora and Trichaptum laricinum. All these species are at least fairly common in the area.

Economically, the most harmful spruce-decaying polypores in the study area are Fomitopsis pinicola, Onnia leporina and Porodaedalea chrysoloma (cf. Norokorpi 1979). Climacocystis borealis is also a noteworthy pathogen, but it is confined to the most luxuriant forests along brooks. Trichaptum laricinum is an aggressive decayer, but its haphazard occurrence gives it only minor importance.

Birch (Betula pubescens) is inhabited by a unique and totally different polypore flora from that of conifers. Fomitopsis pinicola, which grows commonly on birch in southern Finland, appeared almost exclusively on conifers in our present material. We found altogether 20 species which grow on birch, 16 of them exclusively on birch. The most abundant and economically significant pathogenic fungi are $F o m e s$ fomentarius, Inonotus obliquus, Phellinus igniarius (Fig. 8) and Piptoporus betulinus. Typical saprophytic polypores of the Mountain Birch (Betula pubes- 
cens subsp. czerepanovii) are, in addition, Cerrena unicolor, Daedaleopsis septentrionalis, Phellinus laevigatus, $P$. lundellii (Fig. 9), Tyromyces chioneus and T. kmetii. In the upper parts of the fjelds the occurrence of these species is always scattered, evidently because of drought during the growing season.

\section{Polypores of pine forests}

We found 28 species that grow on pine. Typical and fairly abundant species in pine forests are Amyloporia xantha, Antrodia albobrunnea, A. sinuosa, Fuscoporia viticola (Fig. 7), Postia hibernica, P. lowei, Skeletocutis lenis and the two terrestrial species Boletopsis grisea and Coltricia perennis.

There seem to be no polypores in the study area that could be economically significant decayers of living pines. Fomitopsis pinicola causes butt-rot and Porodaedalea pini heart-rot on living pines, but these species are fairly rare on pine in the area. Phaeolus schweinitzii may be a root pathogen of very old pines, though we found it fruiting only once (7522:609; TR 582). It seems to be a significant root pathogen of pine in northern Norway (L. Ryvarden, pers. comm.), although it seldom fruits there.

\section{Threatened and rare polypores at the Northern} Boreal timberline

Threatened species are classified in Finland into four main categories (Rassi et al. 1986, Rassi \& Väisänen 1987): disappeared (D), endangered (E), vulnerable (V) and in need of monitoring (M). The last category is further divided into declining (Md), rare (Mr) and poorly known (Mp). The four main categories accord with international classifications, e.g., the IUCN Red Data Book. The Committee for the Conservation of Threatened Animals and Plants in Finland has prepared a revised list of threatened fungi; it has not yet been published, but the information has been taken into account in this paper. We found altogether 10 threatened (according to the revised list) polypore species in the study area, belonging to the following categories.

Vulnerable (2 species): Amyloporia crassa, Diplomitoporus crustulinus.

In need of monitoring, declining (2 species): Antrodia albobrunnea, Skeletocutis stellae.

In need of monitoring, rare (6 species): Anomoporia myceliosa, Aporpium caryae, Gelatoporia pannocincta, Postia hibernica, P. lowei, Skeletocutis jelicii.

Although including some parasitic, economically significant species (cf. Norokorpi 1979, Niemelä
1988), polypores should certainly not be considered a uniformly harmful group of plant pathogens. About $80 \%$ of the species we found are classified as saprotrophic. They inhabit dead trunks, stumps and branches and are harmless to forestry. In fact, they are beneficial in nutrient recycling, and seem to play an ecologically important role as competitors of saproparasitic decayers. This can be noted in polypore communities of fallen trunks, which abound with, and are often even dominated by pure saprophytes. The role of saprotrophic wood-inhabiting fungi seems to be especially important in northern forests near the timberline, where the structure of the forest ecosystem is fairly simple and the degradation of a single trunk can take over a hundred years: they constitute a balancing factor of special ecological importance.

Fallen trunks can be found on a major scale almost exclusively in virgin forests. This is the main reason why there are now so many rare and endangered species among the wood-inhabiting fungi. The occurrence and distribution of those species clearly depend on the tree species composition of forests and on the abundance and distribution of fallen and decaying trunks. These fungi differ greatly in their microclimatic requirements, need of species associates and other ecological features, but most of the rare and threatened polypores prefer large, fallen, extensively decayed and often partly decorticated trunks, and habitats of stable and high moisture. The survival of many rare polypore species is clearly dependent on an abundant supply of certain common wood-inhabiting fungi. Quantitative studies on the succession, species associates, population dynamics and distribution patterns of wood-rotting fungi are now needed to reveal the structures of fungal communities and the reasons for the presence or absence of a particular species.

In the study area there are many polypores which are considered to be rare or very rare. Although the impression of abundance depends greatly on the observer's working routine and the time spent in the study area, a great number of rare species is a typical character of polypore communities in virgin or little disturbed managed forests. The situation is different as regards the composition of vascular forest plants: a great majority of them are predominant or common, while only a very few species are very rare. Woodrotting fungi considered as rare seem to have a rather significant role in wood decomposition in old forests: although each of them is more or less poor in number, together they make up an important component of the ecosystem. 
Acknowledgements. Financial support from the Academy of Finland (Project No. 01/948, 1988-1990) is gratefully acknowledged. Prof. Teuvo Ahti (Helsinki) and Dr. Seppo Huhtinen (Turku) made valuable amendments to the manuscript. Ms. Anna A. Damström, M.A., revised the English.

\section{References}

Ahti, T., Hämet-Ahti, L. \& Jalas, J. 1968: Vegetation zones and their sections in northwestern Europe. - Ann. Bot. Fennici 5:169-211.

David, A. 1982: Étude monographique du genre Skeletocutis (Polyporaceae). - Naturaliste Canadien 109:235-272.

Donk, M.A. 1960: The generic names proposed for Polyporaceae. - Persoonia 1:173-302.

Donk, M.A. 1974: Check list of European polypores. - Verh. Koninkl. Nederlandsche Akad. Wetensch. Afd. Natuurk., Tweede Reeks 62:1-469.

Eriksson, J. 1949: The Swedish species of the Poria vulgaris group. - Svensk Bot. Tidskr. 43:1-25.

Eriksson, J. 1958: Studies in the Heterobasidiomycetes Aphyllophorales of Muddus National Park in North Sweden. - Symb. Bot. Upsalienses 16(1):1-172.

Eriksson, J. \& Strid, A. 1969: Studies in the Aphyllophorales (Basidiomycetes) of northern Finland. - Rep. Kevo Subarctic Res. Sta. 4:112-158.

Fiasson, J-L. \& Niemelä, T. 1984: The Hymenochaetales, a revision of the European poroid taxa. - Karstenia 24: 14-28.

Fischer, M. 1987: Biosystematische Untersuchungen an den Porlingsgattungen Phellinus Quél. und Inonotus Karst. Bibl. Mycol. 107:1-133.

Gilbertson, R.L. \& Ryvarden, L. 1986: North American polypores 1. Abortiporus-Lindtneria. - Pp. 1-433. Fungiflora, Oslo.

Greuter, W., Burdet, H.M., Chaloner, W.G., Demoulin, V., Grolle, R., Hawskworth, D.L., Nicolson, D.H., Silva, P.C., Stafleu, F.A., Voss, E.G. \& McNeill, J. 1988: International Code of Botanical Nomenclature. - Regnum Vegetabile 118:1-328.

Hämet-Ahti, L., Palmén, A., Alanko, P. \& Tigerstedt, P.M.A. 1989: Suomen puu- ja pensaskasvio. - 290 pp. Dendrologian seura, Helsinki.

Heikinheimo, O. \& Raatikainen, M. 1971: Paikan ilmoittaminen Suomesta talletetuissa biologisissa aineistoissa. The recording of localities of biological finds in Finland. Ann. Entomol. Fennici 37:1-27.

Ingelög, T., Thor, G. \& Gustafsson, L. (eds.) 1984: Floravård i skogsbruket 2. Artdel. - 408 pp. Skogstyrelsen, Jönköping.

Jahn, H. 1967: Trametes hoehnelii (Bres.) und Gloeoporus dichrous (Fr.) als Nachfolger von Inonotus-Arten. - Westfälische Pilzbriefe 6:159-162.

Kotiranta, H. 1984: Skeletocutis jelicii: a new member of the Finnish polypore flora. - Karstenia 24:73-76.

Kotiranta, H. 1986: Skeletocutis lilacina and Tyromyces kmetii, two rare polypore species reported from Finland. Windahlia 16:85-88.

Kotiranta, H. \& Niemelä, T. 1981: Composition of the polypore communities of four forest areas in southern Central Finland. - Karstenia 21:31-48.

Kotlaba, F. \& Pouzar, Z. 1990: Type studies of polypores described by A. Pilát 3. — Ceská Mykol. 44:228-237.
Larsen, M.J. \& Cobb-Poulle, L.A. 1990: Phellinus (Hymenochaetaceae), a survey of the world taxa. - Synopsis Fungorum 3:1-206.

Lowe, J.L. 1956: Type studies of the polypores described by Karsten. - Mycologia 48:99-125.

Niemelä, T. 1972: On Fennoscandian polypores 2. Phellinus laevigatus (Fr.) Bourd. \& Galz. and P. lundellii Niemelä, n. sp. - Ann. Bot. Fennici 9:41-59.

Niemelä, T. 1978a: The occurrence of some rare pore fungi in Finland. - Ann. Bot. Fennici 15:1-6

Niemelä, T. 1978b: On Fennoscandian polypores 6. Antrodia plicata n. sp. - Karstenia 18:43-48.

Niemelä, T. 1982a: Taxonomic notes on the polypore genera Antrodiella, Daedaleopsis, Fibuloporia and Phellinus. Karstenia 22:11-12.

Niemelä, T. 1982b: On Fennoscandian polypores 8. New genus Piloporia. - Karstenia 22:13-16.

Niemelä, T. 1985a: On Fennoscandian polypores 9. Gelatoporia n. gen. and Tyromyces canadensis, plus notes on Skeletocutis and Antrodia. - Karstenia 25:21-40.

Niemelä, T. 1985b: Mycoflora of Poste-de-la-Baleine, northern Québec. Polypores and the Hymenochaetales. - Naturaliste Canadien 112:445-472:

Niemelä, T. 1988: Suomen kääpien määritysopas. — Helsingin yliop. kasvit. lait. monist. 110:1-96.

Norokorpi, Y. 1979: Old Norway spruce stands, amount of decay and decay-causing microbes in northern Finland. Commun. Inst. For. Fenniae 97:1-77.

Overholts, L.O. 1953: The Polyporaceae of the United States, Alaska, and Canada. - 456 pp. Univ. Michigan Press, Ann Arbor.

Rassi, P., Alanen, A., Kemppainen, E., Vickholm, M. \& Väisänen, R. (eds.) 1986: Uhanalaisten eläinten ja kasvien suojelutoimikunnan mietintö 3. Suomen uhanalaiset kasvit. Komiteanmietintö 1985(43). — 431 pp. Ympäristöministeriö, Helsinki.

Rassi, P. \& Väisänen, R. 1987: Threatened animals and plants in Finland. English summary of the report of the Committee for the Conservation of Threatened Animals and Plants in Finland. -82 pp. Ympäristöministeriö, Helsinki.

Rayner, A.D.M. \& Boddy, L. 1988: Fungal decomposition of wood, its biology and ecology. - 587 pp. John Wiley \& Sons, Bath.

Renvall, P., Renvall, T. \& Niemelä, T. 1991: Basidiomycetes at the timberline in Lapland 1. Introduction. - Karstenia 31:1-12.

Ryvarden, L. 1976: The Polyporaceae of North Europe 1. Albatrellus-Incrustoporia. - Pp. 1-214. Fungiflora, Oslo.

Ryvarden, L. 1978: The Polyporaceae of North Europe 2. Inonotus-Tyromyces. - Pp. 215-507. Fungiflora, Oslo.

Ryvarden, L. \& Johansen, I. 1980: A preliminary polypore flora of East Africa. - 636 pp. Fungiflora, Oslo.

Ryvarden, L. 1986: Piloporia sajanensis (Parm.) Niemelä, a rare polypore in Fennoscandia. - Windahlia 16:97-98.

Strid, А. 1981: Incrustoporia sajanensis (Parm.) comb. nov. (Polyporaceae), a taiga species new to Fennoscandia. Wahlenbergia 7:135-139.

Tellería, M.T. 1980: Contribución al estudio de los Aphyllophorales españoles. - Biblioth. Mycol. 74:1-464.

Received on 27 November 1990 